Environment, Biodiversity \& Soil Security
(EBSS)

\title{
Subsoiling Tillage and Compost Applications in Relation to Saline Soil Properties and its Productivity of Wheat
}

El-Hussieny A. Abou Hussien, Wael M. Nada* and Hany Mahrous

Soil Science Dept., Faculty of Agriculture, Menoufia University, Shebin El-Kom 32514, Menoufia, Egypt

\begin{abstract}
$\mathbf{T}$ HIS study aims to clarify the individual and combined effect of both subsoiling tillage and compost on chemical properties of saline soil and its productivity. A field experiment was conducted during winter season of 2018/2019 at El-Hamoul area, Kafr ElSheikh Governorate, Egypt. This experiment included 6 treatments with three replicates (18 plots) where the main factor wastillage (subsoiling tillage, ST; non-subsoiling tillage, NT) and thecompost (sulphur compost, SC; non-sulphur compost, NSC) applied at $24.0 \mathrm{Mgha}^{-1}$ represented the second factor. All plots were sowed by wheat plant. After harvesting, straw and grains were weighted and soil samples of each plot were taken at depths of 0-15, 15-30, 30-45, 45-60 and 60-90 $\mathrm{cm}$ to determinate some chemical properties ( $\mathrm{pH}, \mathrm{EC}, \mathrm{ESP}$ and OM) and the available macronutrients $(\mathrm{N}, \mathrm{P}, \mathrm{K}$ and $\mathrm{S})$ in soil. Compost application without and with subsoiling tillage significantly decreased the soil $\mathrm{pH}$, ESP, EC and increased OM and soil available macronutrients (N, P, K and S). Subsoiling tillage resulted in a significant decrease of soil ESP, EC, OM and the soil available N, P, K and S, while there was slightly increasing in soil $\mathrm{pH}$. Application of compost either without or with ST significantly increased both straw and grains yields of wheat plant compared with control. Treated saline soil with compost and ST had a high positive impact on soil chemical properties and its productivity of wheat plant, where the preference was for ST and SC treatments.
\end{abstract}

Keywords: Salt affected soil; Compost type; Soil SAR; Soil ESP; Soil OM.

\section{Introduction}

The continuous increase of population requires an increase of the nutritional requirements, which depended mainly on the high-quality agricultural lands (Pitman and Läuchli, 2002). Soil productivity decreases as a result of declining its quality parameters (Reeves, 1997). Inappropriate use of agricultural inputs adversely affects the physical, chemical, and biological soil properties (Attard et al. 2011). The excessive use of irrigation water and poor drainage led to the transformation of large areas of land into unproductive lands due to the accumulation of salts in the soil profile occupied by root systems. This soil appears clearly in the arid and semi-arid regions, which is characterized by low rainfall and high rates of evapotranspiration. Due to the low rate of salts leaching, salt accumulates in the surface layers. These salts will negatively affect the soil properties and its crop productivity, and consequently on food security. Therefore, saltaffected soils must be reclaimed to maintain satisfactory levels of fertility for sustaining food production (Tóth et al. 2008 and Elbasiouny et al. 2017).

Tillage impact on nutrient redistribution and availability on plant nutrient uptake is much less covered in the literature compared to the impact on soil physical properties. In general, tillage improves the decomposition of crop residues by facilitating contact between plant tissue and soil aggregate surfaces, the primary biome of

Corresponding author: E-mail: wael_nada22@yahoo.com

Received 31/08/2020; Accepted 4/10/2020

DOI: $10.21608 /$ jenvbs.2020.41236.1105

C2020 National Information and Documentation Center (NIDOC) 
soil microorganisms (Mohammad et al. 2012 and Ji et al. 2015). In addition, tillage distributes organic matter in the soil and thus improves the availability of nutrients for plant growth through the formation of clay-humus complexes and the increase of charged surfaces for nutrient binding. Accumulation of considerable amounts of total nitrogen $(\mathrm{N})$, phosphorus $(\mathrm{P})$, and potassium (K) with conservation tillage was observed (Spiegel et al. 2007; Calegari et al. 2013). However, Calegari et al. (2013) found in the same soil profile higher availability of $\mathrm{P}$ and $\mathrm{K}$ below the $10 \mathrm{~cm}$ layer. The presenceof higher amount of nutrients in the very topsoil $(0-5 \mathrm{~cm})$ under conservation tillage is also supported by different long-term experiments (López-Fando and Pardo, 2009; Gómez-Rey et al. 2012; Ji et al. 2015). Subsoiling tillage will enhance downward movement of irrigation water carrying off excess salts from surface layer. Antar et al. (2008) showed that the soil salinity and sodicity in the topsoil were reduced after subsoiling and moling installation. The reductions of salinity, after three years from experiment installation were $86.71,96.81$ and $98.76 \%$ for subsoiling, moling and subsoiling + moling, respectively over the control and the yields of rice and sugar beet crops increased when the EC decreased as affected by subsoiling and/or moling. Zhang et al. (2009) studied Influence of subsoiling tillage practices on soil properties and crop yields for maize and wheat cultivation in Beijing, China and founded an increase in soil quality and higher crop yield under study in both annual mono-cropping and dual-crop rotation in the area around Beijing. The enhanced parameters included SOM and available $\mathrm{N}$ and $\mathrm{P}$ of the soils under study.

Applying the individual and combined treatments of biofertilizer (bio) + sulphur, bio + compost, and bio + compost + sulphur to saline soil decreased $\mathrm{EC}$ and $\mathrm{pH}$ values in the soil after cultivation, while the values of soil OM were increased (Darwich et al. 2012). Hashemimajd et al. (2012) showed that all levels of S-compost treatment increased soil $\mathrm{P}$ significantly as compared to S treatment. Applied S and compost together show that slight increase values of available N, P and K (Abdelaziz et al. 2016). Also, Saeid (2010) found that the application of organic matter combined with $\mathrm{S}$ greatly increased available N, P, and K content. Alidadi et al. (2013) found that, Sulfurous Granular compost was more effective than others because of micronutrient and macronutrient solubility increase especial
Phosphorus resulting from Sulfurous existence. Fathi et al. (2015) concluded that the application of organic manure and elemental sulphur cause a significant increase in growth, yield of sesame and its components than the control treatment. Saffari et al. (2013) found that sulphur compost is more effective on increase in the number of newly grown leaves of Scindapsus aureus than vermicompost. The objective of this study was to clarify the individual and combined effect of both subsoiling tillage and compost types as amelioration process on chemical properties of saline soil and their productivity of wheat.

\section{Materials and Methods}

\section{Study location and soil sampling}

This study was conducted in newly reclaimed salt affected soil at private farm $\left(31^{\circ} 18^{\prime} 39^{\prime \prime} \mathrm{N}\right.$, $31^{\circ} 07^{\prime} 43^{\prime \prime} \mathrm{E}$ ), which is located in El-Hamoul area, Kafr El-Sheikh Governorate, Egypt. Before planting, disturbed soil samples were taken from the study area using Auger at soil depths of 0-15 (D1), 15-30 (D2), 30-45 (D3), 45-60 (D4) and $60-90 \mathrm{~cm}$ (D5). Soil samples of each depth was air-dried, ground to pass through a $2 \mathrm{~mm}$ sieve, mixed and analyzed for some physical and chemical properties including available macroand micronutrients according to the methods described by Cottenie et al. (1982) and Pageet al. (1982). The presented data in Table 1 show the obtained results.

\section{The applied compost}

In this study, rice straw (RS) as plant residues was a main resource and farmyard manure (FYM) as animal residues and activator was the secondary resource for the compost preparation. Both RS and FYM were collected from the study area. Separately, RS and FYM air-dried and cut to small pieces $(2-4 \mathrm{~cm})$. Two piles in 6 equal height layers were made from mixture of RS and FYM at ratio of 65:35 by weight (Nada, 2015). Simultaneously, the first pile was left without elemental sulfur (S) to produce non-sulphur compost (NSC), while the second mixed with $\mathrm{S}$ at rate of $3 \%$ by weight to obtain a sulphur compost (SC). Further, an activating mixtureof $60 \mathrm{~g}$ of mono calcium phosphate, $134 \mathrm{~g}$ urea and 100 $\mathrm{ml}$ of fresh fertile (soil: water, 1:5) suspension was added for each $20 \mathrm{~kg}$ composted mixture. Both piles were kept moistened at $60 \%$ of its water holding capacity. To improve aeration, the incubated mixtures were turned every two weeks. The composting process continued until $\mathrm{C} / \mathrm{N}$ ratio of the composted materials of NSC and SC 
reached up to 14.7 and 12.38 respectively (60 days). The mature compost (NSC and SC) was air-dried, ground to pass through a $2 \mathrm{~mm}$ sieve and kept at room temperature. Fine compost
(NSC and SC) was analyzed for its chemical composition by using the methods described by Page et al. (1982). The obtained data are recorded in Table 2.

TABLE 1. Initial physical and chemical properties of the experimental salt affected soil and its content of available macro- and micronutrients

\begin{tabular}{|c|c|c|c|c|c|c|c|}
\hline \multirow{2}{*}{ Soil properties } & & \multicolumn{6}{|c|}{ Soil depth (cm) } \\
\hline & & $0-15$ & $15-30$ & $30-45$ & $45-60$ & $60-90$ & Mean \\
\hline \multirow{3}{*}{$\begin{array}{l}\text { Particle size } \\
\text { distribution (\%) }\end{array}$} & Sand & 14.70 & 15.80 & 17.20 & 17.40 & 18.20 & 16.66 \\
\hline & Silt & 30.50 & 32.80 & 33.50 & 34.10 & 33.70 & 32.92 \\
\hline & Clay & 54.80 & 51.40 & 49.30 & 48.50 & 48.10 & 50.42 \\
\hline Texture & & Clay & Clay & Clay & Clay & Clay & Clay \\
\hline Bulk density $\left(\mathrm{g} \mathrm{cm}^{-3}\right)$ & & 1.35 & 1.45 & 1.50 & 1.53 & 1.55 & 1.48 \\
\hline pH & & 8.48 & 8.61 & 8.82 & 8.87 & 9.02 & 8.76 \\
\hline $\mathbf{E C}\left(\mathrm{dS} . \mathrm{m}^{-1}\right)$ & & 10.61 & 9.75 & 8.06 & 6.78 & 5.56 & 8.15 \\
\hline Organic matter (\%) & & 1.75 & 1.22 & 0.81 & 0.58 & 0.50 & 0.97 \\
\hline CEC $\left(\mathrm{cmol} \mathrm{kg}^{-1}\right)$ & & 39.30 & 35.40 & 30.50 & 27.10 & 25.80 & 31.62 \\
\hline $\operatorname{ESP}(\%)$ & & 35.33 & 29.18 & 24.30 & 21.75 & 19.18 & 25.95 \\
\hline \multirow{4}{*}{$\begin{array}{l}\text { Available } \\
\text { macronutrients } \\
\left(\mathrm{mg} \mathrm{kg}^{-1}\right)\end{array}$} & $\mathbf{N}$ & 38.50 & 30.80 & 35.75 & 21.40 & 18.25 & 28.94 \\
\hline & $\mathbf{P}$ & 6.85 & 6.25 & 5.11 & 4.10 & 3.85 & 5.23 \\
\hline & $\mathbf{K}$ & 311.50 & 280.50 & 260.30 & 225.70 & 210.30 & 257.66 \\
\hline & $\mathbf{S}$ & 165.40 & 158.50 & 140.30 & 127.40 & 120.60 & 142.44 \\
\hline \multirow{4}{*}{$\begin{array}{l}\text { Available } \\
\text { micronutrients }\left(\mathrm{mg} \mathrm{kg}^{-1}\right)\end{array}$} & $\mathrm{Fe}$ & 7.33 & 6.80 & 6.05 & 5.46 & 5.40 & 6.21 \\
\hline & Mn & 12.40 & 11.95 & 11.34 & 10.45 & 10.05 & 11.24 \\
\hline & Zn & 2.48 & 2.35 & 2.10 & 1.60 & 1.35 & 1.98 \\
\hline & $\mathrm{Cu}$ & 1.87 & 1.70 & 1.45 & 1.15 & 1.05 & 1.44 \\
\hline
\end{tabular}

$\mathrm{pH}=$ measured in 1:2.5 (soil: water, suspension, $\mathrm{EC}=$ measured in 1:5 (soil: water, extraction), $\mathrm{CEC}=$ Cation exchange capacity, ESP $=$ Exchangeable sodium percentage. 
TABLE 2. Chemical composition of the used non-sulphuric compost (NSC) and sulphuric compost (SC) amendments

\begin{tabular}{ll|cc}
\hline \multicolumn{1}{c|}{ Compost properties } & NSC & SC \\
\hline $\mathbf{p H}$ & & 6.95 & 6.64 \\
$\mathbf{E C}\left(\mathrm{dS} \mathrm{m}^{-1}\right)$ & & 2.24 & 2.65 \\
Organic matter (\%) & 43.10 & 39.50 \\
Total carbon (\%) & & 25.00 & 22.91 \\
Total nitrogen (\%) & & 1.70 & 1.85 \\
\hline & $\mathbf{N}$ & 860.0 & 1105.0 \\
& $\mathbf{P}$ & 685.0 & 792.0 \\
Available macronutrients $\left(\mathrm{mg} \mathrm{kg}^{-1}\right)$ & $\mathbf{K}$ & 2050.0 & 2178.0 \\
& $\mathbf{S}$ & 250.0 & 2117.0 \\
\hline & $\mathbf{F e}$ & 380.0 & 750.0 \\
& $\mathbf{M n}$ & 485.0 & 525.0 \\
Available micronutrients $\left(\mathrm{mg} \mathrm{kg}^{-1}\right)$ & $\mathbf{Z n}$ & 58.0 & 75.0 \\
& $\mathbf{C u}$ & 15.0 & 25.0 \\
\hline
\end{tabular}

$\mathrm{pH}=$ measured in 1:10 (compost: distilled water, suspension, $\mathrm{EC}=$ measured in 1:20 (compost: distilled water, extraction), NSC = nonsulphur compost, $\mathrm{SC}=$ sulphur compost.

\section{Field experiment}

A field experiment was conducted during winter growing seasons 2018/2019. The study area $\left(2160 \mathrm{~m}^{2}\right)$ was divided into 18 equal experimental plots $(6 \times 20 \mathrm{~m})$. These plots represented two main groups ( 9 plots/ group) of subsoiling tillage (ST) and non-subsoiling tillage (NT). The ST plots were ploughed to $55 \mathrm{~cm}$ depth with spikes spaced at $61 \mathrm{~cm}$ (chisel subsoiler consist of 3 plows). In this situation, rupture width in soil surface was found to be $30-35 \mathrm{~cm}$. While the NT plots were prepared by using conventional tillage. The plots of each main group (ST and NT) were divided into 3 subgroups (3 plots /subgroup): the first left without compost $(\mathrm{C} 0)$, the second and third were fertilized by non-sulphur compost (NSC) and sulphur compost (SC), respectively. After plowing, all plots were treated with ordinary super phosphate $\left(15.5 \% \mathrm{P}_{2} \mathrm{O}_{5}\right.$, at $\left.476.2 \mathrm{kgha}^{-1}\right)$ and potassium sulfate $\left(48.0 \% \mathrm{~K}_{2} \mathrm{O}\right.$, at $\left.119.1 \mathrm{kgha}^{-1}\right)$. Together, separately the types (NSC and SC) of compost were added at mixed ratio of 0.0 and 24.0 $\mathrm{Mgha}^{-1}$, respectively. The additive treatments were thoroughly mixed with soil by using conventional plows. Then the plots were crawled till it were sowed. Each plot was divided into 6 furrows with $60 \mathrm{~cm}$ wide and separated by 30 $\mathrm{cm}$ distance. Wheat grains of Triticum aestivum L. (cvMisr 2) were planted on 20 November of 2018. Other farming practices were performed according to the recommendation of the Egyptian Ministry of Agriculture for wheat planting under salt affected soil conditions. After 21 days of planting, all plots were fertilized by ammonium nitrate $(33.0 \% \mathrm{~N})$ at rate of $428.6 \mathrm{kgha}^{-1}$. Other equal dose of $\mathrm{N}$ was added after 42 days of planting. At maturity stage, the plants of each plot were harvested. The grains were separated from straw and weighted in order to estimate the grains and straw fresh yield as $\mathrm{Mgha}^{-1}$. Then soil samples at different depths (D1, D2, D3, D4 and D5) were taken from each plot by auger, air-dried, ground to pass through a $2 \mathrm{~mm}$ sieve and analyzed for some chemical properties and available macroand micronutrients content (Cottenie et al. 1982 and Page et al. 1982). Relative change (RC) and agronomic efficiency (AE) of straw and grains yields were calculated according to equations 1 and 2 , respectively. 


$$
\mathrm{RC}(\%)=\frac{\text { Data of treatment }- \text { Data of control }}{\text { Added compost }\left(24.0 \mathrm{Mg} \cdot \mathrm{ha}^{-1}\right)} \times 100 \quad \text { Equation } 1
$$

$$
\mathrm{AE}\left(\mathrm{MgMg}^{-1}\right)=\frac{\text { Data of treatment }- \text { Data of control }}{\text { Added compost }\left(24.0 \mathrm{Mg} \cdot \mathrm{ha}^{-1}\right)} \quad \text { Equation } 2
$$

\section{Statistical analysis}

The obtained data were statistically analyzed according to Snedecor and Cochran (1980). The least significant difference (LSD) range test was used to compare different treatment means in each group of means to see which are significantly different. Significantly different was calculated at a 5\% level of probability unless otherwise indicated. The effect of studied treatments on soil chemical properties (EC, $\mathrm{OM}, \mathrm{ESP})$ and soil available macronutrients $(\mathrm{N}$, $\mathrm{P}, \mathrm{K}, \mathrm{S}$ ) were examined by the 3-way ANOVA randomized blocks method. While the splitplot ANOVA procedure was used to test the effect of both tillage and applied compost treatments on straw and grain yield of wheat plant.

\section{Results}

Effect of the studied treatments on soil chemical properties

Soil reaction $(\mathrm{pH})$

Data in Figs. (1-A; 1-B) show that, with all treatments $(\mathrm{C} 0, \mathrm{NSC}, \mathrm{SC}, \mathrm{NT}$, and $\mathrm{ST})$ soil $\mathrm{pH}$ increased with the increase of soil depth. The

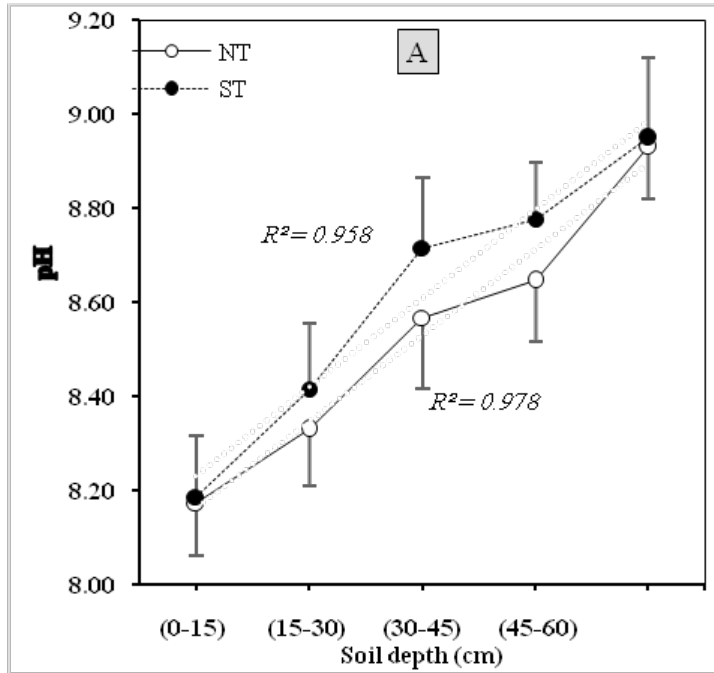

highest $\mathrm{pH}$ values (8.97) appeared with 60-90 $\mathrm{cm}$ layer, while the lowest one (8.18) recorded to surface layer $(0-15 \mathrm{~cm})$. Regarding to the effect of subsoiling tillage, data indicated that ST tillage associated by an increase of soil $\mathrm{pH}$ as shown in Fig. 1-A. After wheat crop, the lowest $\mathrm{pH}$ value of 8.50 was observed in NT treatments against the highest value of 8.67 of ST treatments. There is a positive relationship $\left(R^{2}=0.99\right)$ among soil $\mathrm{pH}$ and soil depth for both ST and NS treatments (Fig. 1-A). According to the effect of compost types (NSC and SC), data indicated that, application of compost either with ST or NT treatments resulted in a positive decrease of soil $\mathrm{pH}$ (Fig.1-B). The found decrease of $\mathrm{pH}$ in soil manured by SC was higher than that found in the soil manured by NSC with the two treatments of NT and ST. The 1\% SC treatment exhibited a minimum value of soil $\mathrm{pH}(8.38)$ and the untreated soil $(\mathrm{C} 0)$ observed with the maximum value (8.74) of soil $\mathrm{pH}$. Individually, soil $\mathrm{pH}$ in NSC and SC treatments increased positively $\left(R^{2}\right.$ $=0.98 ; 0.99$, respectively) with increasing soil depth (Fig. 1-B).

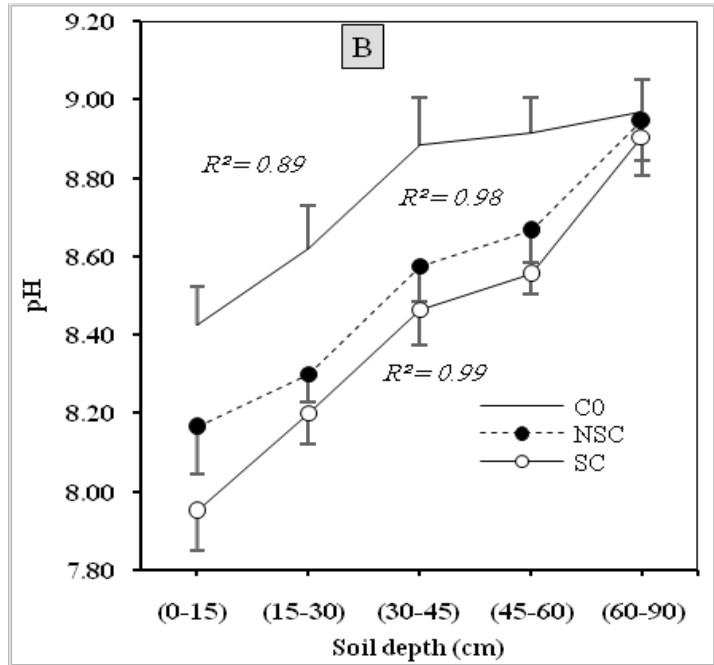

Fig. 1. Individual effect of tillage (A) and compost types (B) on the pH values (mean \pm standard deviation) of salt affected soil in different layers of soil profile. $\mathrm{NT}=$ non-subsoiling tillage, $\mathrm{ST}=$ subsoiling tillage, $\mathrm{C0}=$ untreated soil, NSC $=$ non-sulphuric compost, $\mathrm{SC}=$ sulphuric compost 


\section{Soil electrical conductivity (EC)}

The differences of EC values of soil depths were significant as shown in Table 3 and Figs. (2-A; 2-B). D1 $(0-15 \mathrm{~cm})$ showing the maximum significant values $\left(8.66 \mathrm{dSm}^{-1}\right)$ of EC in contract to $5.30 \mathrm{dS} . \mathrm{m}^{-1}$ for D5 $(60-90 \mathrm{~cm})$. The subsoiling tillage (ST) associated by a significant decrease of soil EC values compared to the non-subsoiling tillage (NT) treatment as shown in Table 3 and Fig. 2-A. The high significant value (7.37 $\mathrm{dSm}^{-1}$ ) of EC was associated with NT treatment, while the lowest value $\left(6.66 \mathrm{dSm}^{-1}\right)$ recorded to $\mathrm{T}$ treatment. This was supported with the invers relationships between soil EC and soil depth in both ST $\left(R^{2}=0.97\right)$ and NT $\left(R^{2}=0.96\right)$ treatments (Fig. 2-A). The presented data in Table 3 and illustrated by Fig. 2-B, reveal that, EC values $\left(6.69 \mathrm{dSm}^{-1}\right)$ of the treatment of SC were lower than those $\left(6.98 \mathrm{dSm}^{-1}\right)$ found with the treatment of NSC, where these variations were significant. The soil EC appeared in strongly invers relationships with increasing soil depth for $\mathrm{C} 0$ $\left(R^{2}=0.96\right), \mathrm{NSC}\left(R^{2}=0.97\right)$ and $\mathrm{SC}\left(R^{2}=0.98\right)$ treatments (Fig. 2-B). Also, statistical analyses of the obtained data showed that, all possibility of the four interaction are significantly affected in the soil EC values (Table 3; F-test).

\section{Soil organic matter (OM)}

Generally, soil OM decreased with increasing of soil depth under all experimental treatments (Table 3; Fig. 3-A \& B). Surface layer achieved the highest value $(2.14 \%)$ of $\mathrm{OM}$ content, in contrast of the deeper layer $(0.60 \%)$. Within different layer of soil profile, application of ST tillage decreased significantly soil OM content, compared with NT treatments. The mean values of soil OM content were $1.27 \%$ and $1.13 \%$ in the NT and ST plots, respectively (Table 3; Fig.3-A). with both ST and NT treatments, a strong inverse relationship $\left(R^{2}=0.93\right)$ were appeared between soil OM and soil depth (Fig. 3-A). Either NSC or $\mathrm{SC}$ application resulted in a significant increase of OM content in the different layers of soil profile and more increases associated with NSC. The effect of studied treatments on the increase of OM took the following order: $\mathrm{NSC}>\mathrm{SC}>$ C0 (Table 3; Fig.3-B). Also, accompanied the increases of soil depth, a strong inverse relation of soil OM content in C0 $\left(R^{2}=0.87\right)$, NSC $\left(R^{2}\right.$ $=0.96)$ and $\mathrm{SC}\left(R^{2}=0.93\right)$ treatments. Further more, the results of Table 3 (F-test) showed that the soil OM content was significantly affected by the interaction among all of the studied factors.

\section{Soil exchangeable sodium percent (ESP)}

Data in Table 3 and Fig 4 (A \& B) show that with increasing in the soil depth of layers, the soil ESP values were significantly decreasing with all experimental. The lowest ESP value (17.98\%) was associated with the deeper layer $(60-90 \mathrm{~cm})$, while the highest value $(29.43 \%)$ was in favor of the surface layer $(0-15 \mathrm{~cm})$. Plowing soil by ST resulted in a significant decrease of soil ESP, compared with that of NT treatment (Table 3). The mean values of soil ESP were $22.61 \%$ and $23.92 \%$ in the ST and NT plots, respectively. Also, there is a strong inverse relationship $\left(R^{2}=\right.$ 0.98 ) between ESP and soil depth for both ST and NT treatments (Fig. 4-A). Compost application either NSC or SC resulted in a significant decrease of ESP values in the different layers of soil profile. The high decrease associated with SC (Table 3 \& Fig. 4-B). Based on the mean values of ESP, the studied treatments effect on the decrease of soil ESP took the following order: $\mathrm{SC}<\mathrm{NSC}<\mathrm{C} 0$. The lowest significant ESP value $(21.69 \%)$ recorded to $\mathrm{SC}$ treatment against the highest values $(25.36 \%)$ of control. Also, there was an inverse correlation $\left(R^{2}=0.98\right)$ between soil depth and ESP values, as was evident with C0, NSC and SC treatments (Fig. 4-B). Also, a positive significant of interaction between all studied 3 factors were evident on soil content of ESP (Table 3 \& F-test).

\section{Effect of the studied treatments on soil content of available macronutrients}

The presented data in Table 4 show the effect of the studied treatments, i.e. subsoiling tillage, compost type at rate of $1 \%$ (NSC and SC) and depth (D1, D2, D3, D4 and D5) on soil content of some available macro-nutrients $(\mathrm{N}$, $\mathrm{P}, \mathrm{K}$ and $\mathrm{S}$ ). These data show that, the studied treatments have a significant effect on the soil content of available macronutrients under study. These contents of available N, P, K and S decreased with the increase of soil depth under all studied treatments. The highest significant value of available macronutrients recorded to surface layer $(0-15 \mathrm{~cm})$ and it were $10.48,7.17$, 325.18 , and $180.90 \mathrm{mgkg}^{-1}$ for $\mathrm{N}, \mathrm{P}, \mathrm{K}$, and $\mathrm{S}$, respectively. While the D5 $(60-90 \mathrm{~cm})$ observed with the lowest values of $\mathrm{N}\left(20.45 \mathrm{mgkg}^{-1}\right), \mathrm{P}$ (4.52 $\left.\mathrm{mgkg}^{-1}\right), \mathrm{K}\left(213.53 \mathrm{mgkg}^{-1}\right)$, and $\mathrm{S}(124.77$ $\left.\mathrm{mgkg}^{-1}\right)$. With regard to the subsoiling tillage (ST), data indicated that, the contents of available $\mathrm{N}, \mathrm{P}, \mathrm{K}$ and $\mathrm{S}$ with the treatment of subsoiling tillage were less than their contents in nonsubsoiling tillage as listed in Table 4 . The plots 
treated with ST treatment reveals with 28.56 , 5.60, 267.89 and $148.59 \mathrm{mgkg}^{-1}$ values for soil available $\mathrm{N}, \mathrm{P}, \mathrm{K}$, and $\mathrm{S}$ respectively. However, the high significant values of $30.87 \mathrm{mgkg}^{-1}(\mathrm{~N})$, $6.13 \mathrm{mgkg}^{-1}(\mathrm{P}), 275 \mathrm{mgkg}^{-1}(\mathrm{~K})$, and 154.46 $\mathrm{mgkg}^{-1}(\mathrm{P})$ accompanied the NT treatment (Table 4). According to the effect of added compost types (NSC and SC), data indicated that, application of compost either without or with subsoiling tillage resulted in a significant increase of the contents of soil available macro-nutrients $(\mathrm{N}, \mathrm{P}$, $\mathrm{K}$ and $\mathrm{S}$ ) compared with the control. The highest significant value of available $\mathrm{N}\left(33.86 \mathrm{mgkg}^{-1}\right)$, $\mathrm{P}\left(6.69 \mathrm{mgkg}^{-1}\right), \mathrm{K}\left(285.52 \mathrm{mgkg}^{-1}\right)$, and S (161.62 $\left.\mathrm{mgkg}^{-1}\right)$ were observed with the soil treated by SC treatment. In contrast, the lowest significant values of $\mathrm{N}\left(24.18 \mathrm{mgkg}^{-1}\right), \mathrm{P}\left(4.96 \mathrm{mgkg}^{-1}\right), \mathrm{K}$ $\left(250.25 \mathrm{mgkg}^{-1}\right)$, and $\mathrm{S}\left(139.79 \mathrm{mgkg}^{-1}\right)$ appeared with untreated plots (Table 4). In addition, the results in Table 4 (F-test) showed that, the available $\mathrm{N}, \mathrm{P}$ and $\mathrm{S}$ were significantly affected by the interaction of all examined factors. In contrast, soil available $\mathrm{K}$ was significantly affected by only the interaction between compost types and soil depth.

TABLE 3. Effect of subsoiling and non-subsoiling tillage and compost types on some chemical properties of salt affected soil in different layers of soil profile

\begin{tabular}{|c|c|c|c|}
\hline Treatments & $\begin{array}{c}E C \\
\left(\mathbf{d S} \mathbf{m}^{-1}\right)\end{array}$ & $\begin{array}{l}\text { OM } \\
(\%)\end{array}$ & $\begin{array}{l}\text { ESP } \\
(\%)\end{array}$ \\
\hline \multicolumn{4}{|c|}{ a) Tillage types } \\
\hline NT & $7.37 \pm 1.56 \mathrm{a}$ & $1.27 \pm 0.67 \mathrm{a}$ & $23.92 \pm 4.73 \mathrm{a}$ \\
\hline ST & $6.66 \pm 1.14 \mathrm{~b}$ & $1.13 \pm 0.57 \mathrm{~b}$ & $22.61 \pm 4.36 \mathrm{~b}$ \\
\hline LSD 0.05 & 0.086 & 0.056 & 0.092 \\
\hline \multicolumn{4}{|c|}{ b) Compost type } \\
\hline $\mathrm{C} 0$ & $7.38 \pm 1.59 \mathrm{a}$ & $0.90 \pm 0.45 \mathrm{c}$ & $25.36 \pm 5.21 \mathrm{a}$ \\
\hline NSC & $6.98 \pm 1.35 \mathrm{~b}$ & $1.39 \pm 0.64 \mathrm{a}$ & $22.75 \pm 3.99 \mathrm{~b}$ \\
\hline $\mathrm{SC}$ & $6.69 \pm 1.22 \mathrm{c}$ & $1.31 \pm 0.66 \mathrm{~b}$ & $21.69 \pm 3.69 \mathrm{c}$ \\
\hline LSD 0.05 & 0.047 & 0.045 & 0.198 \\
\hline \multicolumn{4}{|c|}{ c) Soil depth $(\mathrm{cm})$} \\
\hline $0-15$ & $8.66 \pm 0.99 \mathrm{a}$ & $2.14 \pm 0.38 \mathrm{a}$ & $29.43 \pm 2.96 \mathrm{a}$ \\
\hline $15-30$ & $8.19 \pm 0.81 \mathrm{~b}$ & $1.47 \pm 0.27 \mathrm{~b}$ & $26.36 \pm 2.38 \mathrm{~b}$ \\
\hline $30-45$ & $6.94 \pm 0.28 \mathrm{c}$ & $1.05 \pm 0.31 \mathrm{c}$ & $22.24 \pm 1.57 \mathrm{c}$ \\
\hline $45-60$ & $5.98 \pm 0.29 \mathrm{~d}$ & $0.72 \pm 0.15 \mathrm{~d}$ & $20.30 \pm 1.25 \mathrm{~d}$ \\
\hline $60-90$ & $5.30 \pm 0.22 \mathrm{e}$ & $0.60 \pm 0.09 \mathrm{e}$ & $17.98 \pm 0.88 \mathrm{e}$ \\
\hline LSD 0.05 & 0.042 & 0.045 & 0.27 \\
\hline \multicolumn{4}{|l|}{ F test } \\
\hline Tillage * Compost & $* *$ & $* *$ & $* *$ \\
\hline Tillage * Depth & $* *$ & $*$ & $*$ \\
\hline Compost * Depth & $* *$ & $* *$ & $* *$ \\
\hline Tillage $*$ Compost $*$ Depth & $* *$ & $* *$ & $* *$ \\
\hline
\end{tabular}

$\mathrm{NT}=$ non-subsoiling tillage treatments; $\mathrm{ST}=$ subsoiling tillage treatments; $\mathrm{C} 0=$ untreated soil, $\mathrm{NSC}=$ non-sulphur compost treatment; $\mathrm{SC}=$ sulphur compost treatment; $*=$ significant at 0.05 probability level; $* *=$ significant at 0.01 probability level; values presented in columns are mean \pm standard deviation, mean values within each column followed by same letters are not significantly different at $5 \%$ level of probability. 

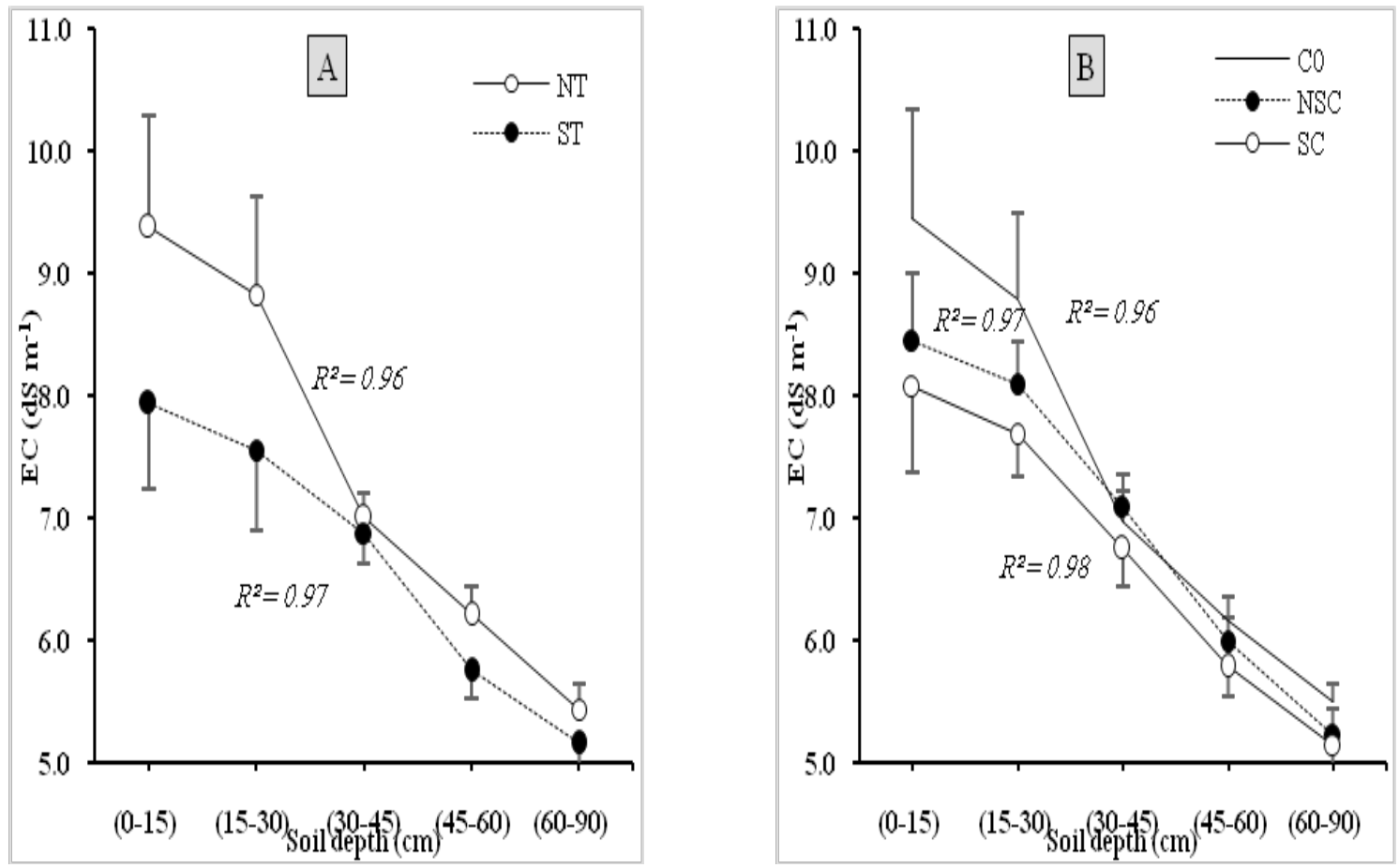

Fig. 2. Individual effect of tillage (A) and compost types (B) on the EC values (mean \pm standard deviation) of salt affected soil in different layers of soil profile. $\mathrm{EC}=$ electrical conductivity, $\mathrm{NT}=$ non-subsoiling tillage, $\mathrm{ST}$ $=$ subsoiling tillage, $\mathrm{CO}=$ untreated soil, $\mathrm{NSC}=$ non-sulphuric compost, $\mathrm{SC}=$ sulphuric compost
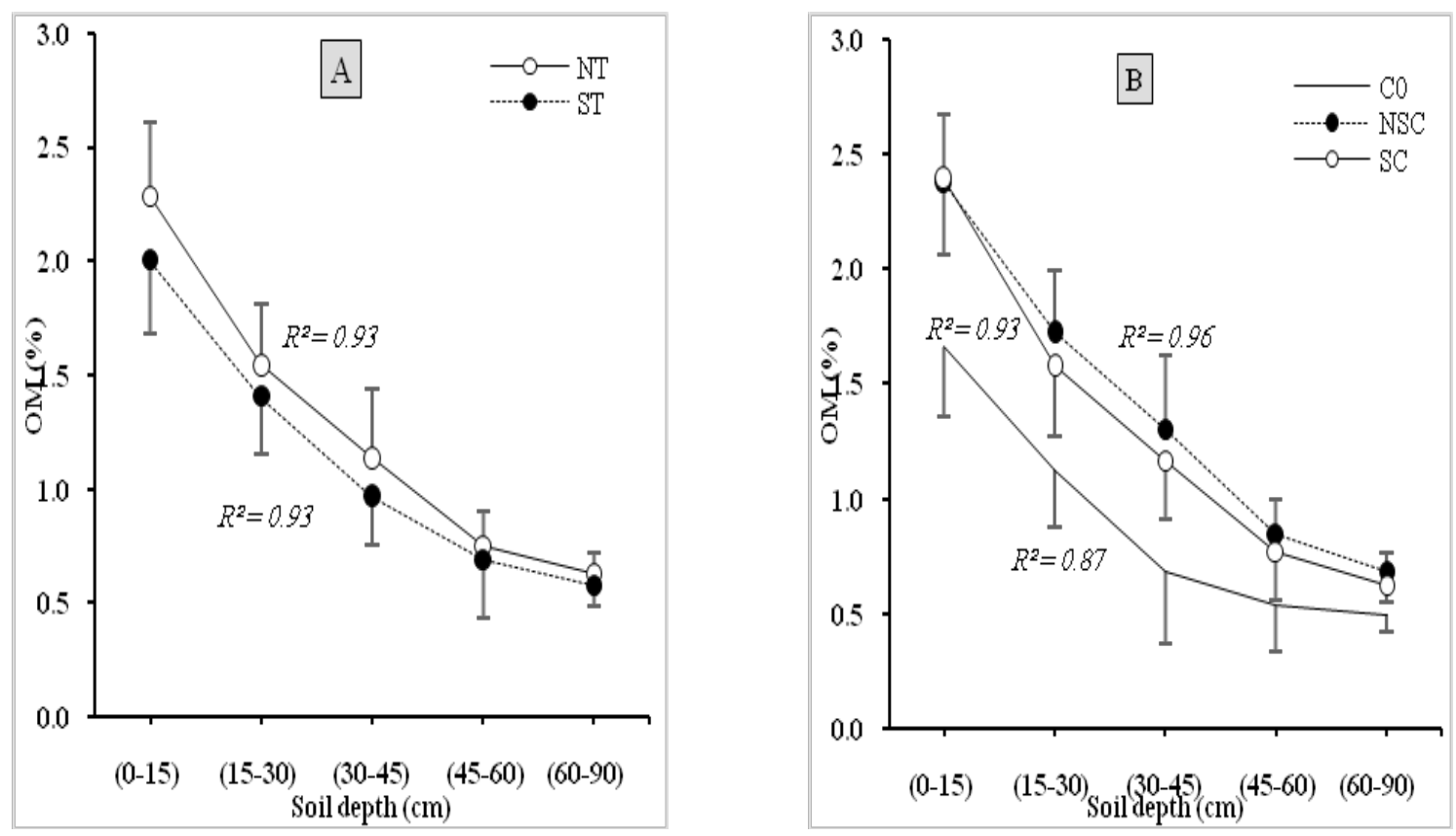

Fig. 3. Individual effect of tillage (A) and compost types (B) on the OM content (mean \pm standard deviation) of salt affected soil in different layers of soil profile. $\mathrm{OM}=$ organic matter, $\mathrm{NT}=$ non-subsoiling tillage, $\mathrm{ST}=$ subsoiling tillage, $\mathrm{CO}=$ untreated soil, $\mathrm{NSC}=$ non-sulphuric compost, $\mathrm{SC}=$ sulphuric compost 

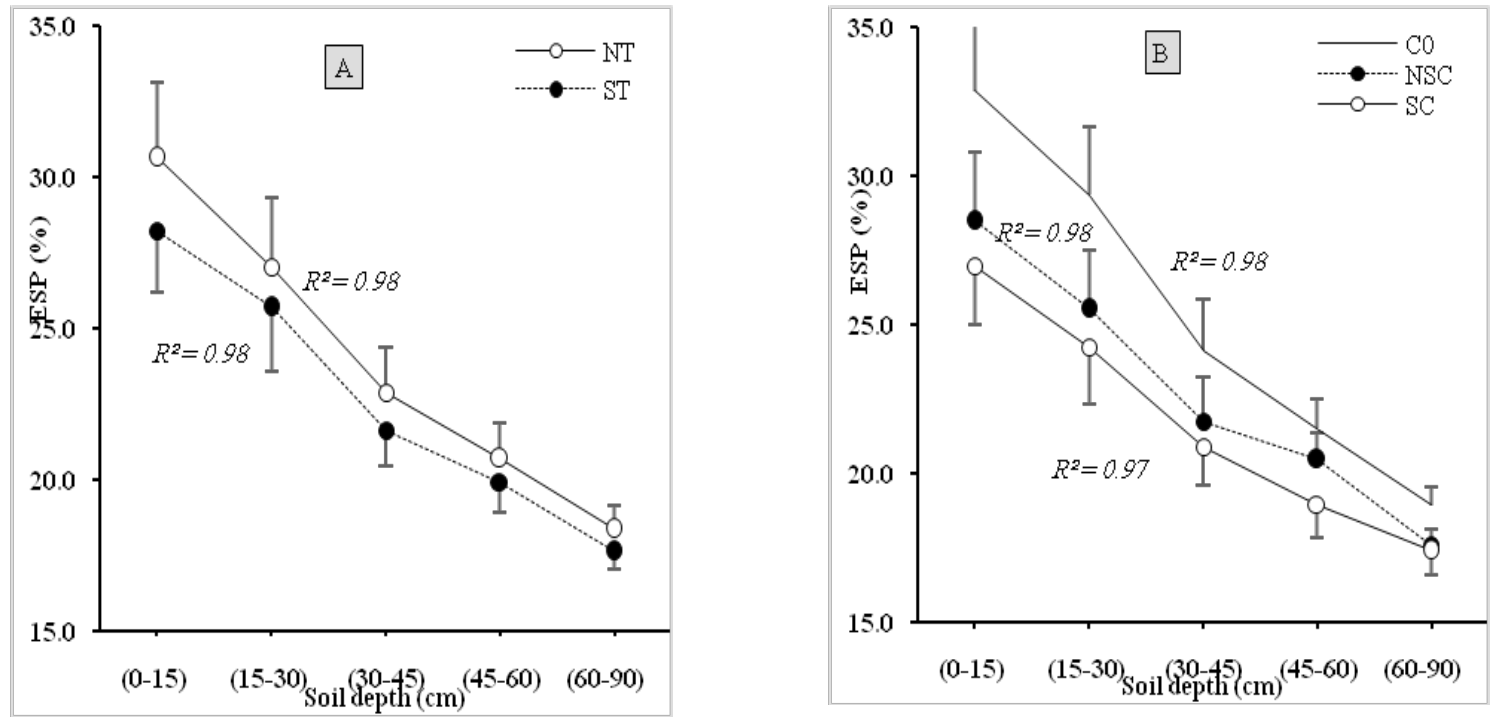

Fig. 4. Individual effect of tillage (A) and compost types (B) on the ESP values (mean \pm standard deviation) of salt affected soil in different layers of soil profile. $\mathrm{ESP}=$ exchangeable sodium percentage, $\mathrm{NT}=$ non-subsoiling tillage, $\mathrm{ST}=$ subsoiling tillage, $\mathrm{C} 0=$ untreated soil, $\mathrm{NSC}=$ non-sulphuric compost, $\mathrm{SC}=$ sulphuric compost

TABLE 4. Effect of subsoiling and non-subsoiling tillage and compost types on soil available macronutrients (N, P, $K$ and $S$ ) contents in different layers of soil profile

\begin{tabular}{|c|c|c|c|c|}
\hline Treatments & $\begin{array}{c}N \\
\left(\mathrm{mg} \mathrm{kg}^{-1}\right)\end{array}$ & $\begin{array}{c}\mathbf{P} \\
\left(\mathrm{mg} \mathrm{kg}^{-1}\right)\end{array}$ & $\begin{array}{c}\mathrm{K} \\
\left(\mathrm{mg} \mathrm{kg}^{-1}\right)\end{array}$ & $\begin{array}{c}S \\
\left(\mathrm{mg} \mathrm{kg}^{-1}\right)\end{array}$ \\
\hline \multicolumn{5}{|c|}{ a) Tillage types } \\
\hline NT & $30.87 \pm 8.89 \mathrm{a}$ & $6.13 \pm 1.29 \mathrm{a}$ & $275.37 \pm 47.19 \mathrm{a}$ & $154.46 \pm 25.06 \mathrm{a}$ \\
\hline ST & $28.56 \pm 7.90 \mathrm{~b}$ & $5.60 \pm 1.13 \mathrm{~b}$ & $267.89 \pm 41.94 \mathrm{~b}$ & $148.59 \pm 21.29 b$ \\
\hline LSD 0.05 & 0.297 & 0.095 & 7.220 & 0.840 \\
\hline \multicolumn{5}{|c|}{ b) Compost type } \\
\hline $\mathrm{C} 0$ & $24.18 \pm 5.74 \mathrm{c}$ & $4.96 \pm 1.04 \mathrm{c}$ & $250.25 \pm 30.80 \mathrm{c}$ & $139.79 \pm 19.38 \mathrm{c}$ \\
\hline $\mathrm{NSC}$ & $31.10 \pm 7.88 b$ & $5.95 \pm 0.96 b$ & $279.12 \pm 44.49 b$ & $153.09 \pm 20.94 b$ \\
\hline $\mathrm{SC}$ & $33.86 \pm 8.53 \mathrm{a}$ & $6.69 \pm 0.98 \mathrm{a}$ & $285.52 \pm 48.65 \mathrm{a}$ & $161.62 \pm 27.31 \mathrm{a}$ \\
\hline LSD 0.05 & 0.196 & 0.045 & 7.430 & 1.397 \\
\hline \multicolumn{5}{|c|}{ c) Soil depth $(\mathrm{cm})$} \\
\hline $0-15$ & $40.48 \pm 5.26 \mathrm{a}$ & $7.17 \pm 0.70 \mathrm{a}$ & $325.18 \pm 25.42 \mathrm{a}$ & $180.90 \pm 17.23 \mathrm{a}$ \\
\hline $15-30$ & $34.32 \pm 6.67 \mathrm{~b}$ & $6.68 \pm 0.77 \mathrm{~b}$ & $302.18 \pm 24.62 b$ & $168.17 \pm 13.78 b$ \\
\hline $30-45$ & $28.92 \pm 4.41 \mathrm{c}$ & $5.79 \pm 0.82 \mathrm{c}$ & $272.02 \pm 15.98 \mathrm{c}$ & $147.80 \pm 10.61 \mathrm{c}$ \\
\hline $45-60$ & $24.32 \pm 3.67 \mathrm{~d}$ & $5.17 \pm 1.13 \mathrm{~d}$ & $245.23 \pm 28.80 \mathrm{~d}$ & $135.87 \pm 16.21 \mathrm{~d}$ \\
\hline $60-90$ & $20.54 \pm 1.95 \mathrm{e}$ & $4.52 \pm 0.62 \mathrm{e}$ & $213.53 \pm 4.38 \mathrm{e}$ & $124.77 \pm 5.07 \mathrm{e}$ \\
\hline LSD 0.05 & 0.187 & 0.059 & 6.861 & 2.960 \\
\hline \multicolumn{5}{|l|}{ F test } \\
\hline Tillage $*$ Compost & $* *$ & $* *$ & ns & $* *$ \\
\hline Tillage * Depth & $*$ & $*$ & ns & $*$ \\
\hline Compost * Depth & $* *$ & $* *$ & $* *$ & $* *$ \\
\hline Tillage $*$ Compost $*$ Depth & $* *$ & $*$ & ns & $* *$ \\
\hline
\end{tabular}

$\mathrm{NT}=$ non-subsoiling tillage treatments; $\mathrm{ST}=$ subsoiling tillage treatments; $\mathrm{C} 0=$ untreated soil, $\mathrm{NSC}=$ non-sulphur compost treatment; $\mathrm{SC}=$ sulphur compost treatment; $\mathrm{ns}=$ non-significant; $*=$ significant at 0.05 probability level; $* *=$ significant at 0.01 probability level; values presented in columns are mean \pm standard deviation, mean values within each column followed by same letters are not significantly different at $5 \%$ level of probability. 
Effect of the studied treatments on straw and grain yield of wheat plants

The presented data in Tables 5 and 6 showed the effect of compost types (NSC; SC) and the modality of tillage (ST; NT) on straw and grains yields of wheat plants (Misr 2). Application of compost either with ST or NT resulted in a significant increase in both straw and grains yield of wheat plant compared with control (Table 5). Wheat plant grown in the ST treatments gave the highest values of straw $\left(9.45 \mathrm{Mgha}^{-1}\right)$ ) and grain $\left(8.67 \mathrm{Mgha}^{-1}\right)$ yields, while the lowest yield of 9.14 $\mathrm{Mgha}^{-1}$ (straw) and 8.29 $\mathrm{Mgha}^{-1}$ (grain), recorded to the NT plots. Although the found decreases in the soil content of N, P, K and S in ST plots (Table 4), which resulted from the leaching and plant high uptake, data in Table 5 show significant increases of straw and grains yield of wheat plants grown in ST treatment. Both two types of the applied compost (SC; NSC) showed significant differences on straw and grain yields when compared with control, With proven superiority to $\mathrm{SC}$ treatment. The prominent yields for both straw (10.50 $\left.\mathrm{Mgha}^{-1}\right)$ and grain (9.80
$\mathrm{Mgha}^{-1}$ ) accompanied the SC treatment, while the deteriorated one of $7.71 \mathrm{Mg} \cdot \mathrm{ha}^{-1}$ (straw) and 6.76 $\mathrm{Mgha}^{-1}$ (grain) noticed in untreated soil (Table 5). Also, the combination between tillage and compost treatments produced a strong interaction on both straw and grain yields (Table 5; F-test). Moreover, with the two treatments of NT and ST, the obtained values of relative change (RC) and agronomic efficiency (AE) of straw and grains yields of wheat plants grown in soil treated by $\mathrm{SC}$ were higher than those found with the plants manured by NSC (Table 6). The highest RC value of straw $(37.56 \%)$ and grain $(47.74 \%)$ was appeared with ST plots that treated with SC compost, against the lowest $\mathrm{RC}$ values $(24.96 \%$ and $31.47 \%$, respectively) of NT treatments accompany the NSC compost. Similarly, the highest $\mathrm{AE}$ values of straw $\left(0.123 \mathrm{MgMg}^{-1}\right)$ and grains $\left(0.137 \mathrm{MgMg}^{-1}\right)$ yields recorded to ST and $\mathrm{SC}$ treatments. In contract, the NT plots treated with NSC compost occurred the lowest values of AE for straw $\left(0.080 \mathrm{MgMg}^{-1}\right)$ and grains $(0.088$ $\left.\mathrm{MgMg}^{-1}\right)$ of wheat plant.

TABLE 5. Effect of subsoiling and non-subsoiling tillage and compost types on straw and grains yield of wheat plants

\begin{tabular}{|c|c|c|}
\hline Treatments & $\begin{array}{c}\text { Straw fresh yield } \\
\left(\mathrm{Mg} \mathrm{ha}^{-1}\right)\end{array}$ & $\begin{array}{c}\text { Grain fresh yield } \\
\left(\mathrm{Mg} \mathrm{ha}^{-1}\right)\end{array}$ \\
\hline \multicolumn{3}{|c|}{ a) Tillage types } \\
\hline NT & $9.14 \pm 1.29 b$ & $8.29 \pm 1.16 b$ \\
\hline $\mathrm{ST}$ & $9.45 \pm 1.18 \mathrm{a}$ & $8.67 \pm 1.05 \mathrm{a}$ \\
\hline LSD 0.05 & 0.039 & 0.084 \\
\hline \multicolumn{3}{|c|}{ b) Compost type } \\
\hline $\mathrm{C} 0$ & $7.71 \pm 0.10 \mathrm{c}$ & $6.74 \pm 0.13 \mathrm{c}$ \\
\hline $\mathrm{NSC}$ & $9.67 \pm 0.16 b$ & $8.90 \pm 0.36 b$ \\
\hline $\mathrm{SC}$ & $10.50 \pm 0.26 \mathrm{a}$ & $9.81 \pm 0.39 \mathrm{a}$ \\
\hline LSD 0.05 & 0.039 & 0.049 \\
\hline \multicolumn{3}{|l|}{ F test } \\
\hline Tillage $*$ Compost & $* *$ & $* *$ \\
\hline
\end{tabular}

Env. Biodiv. Soil Security Vol. 4 (2020) 
TABLE 6. Relative change and agronomic efficiency of straw and grain yield of wheat plant as affected by subsoiling and non-subsoiling tillage and compost types

\begin{tabular}{cccccc}
\hline \multirow{2}{*}{ Tillage type } & Compost type & \multicolumn{2}{c}{ Straw } & \multicolumn{2}{c}{ Grain } \\
\cline { 3 - 6 } & & $\begin{array}{c}\mathbf{R C} \\
\mathbf{( \% )}\end{array}$ & $\begin{array}{c}\mathbf{A E} \\
\left(\mathbf{M g ~ M g}^{-1}\right)\end{array}$ & $\begin{array}{c}\mathbf{R C} \\
\mathbf{( \% )}\end{array}$ & $\begin{array}{c}\mathbf{A E} \\
\left(\mathbf{M g ~ M g}^{-1}\right)\end{array}$ \\
\hline \multirow{3}{*}{$\mathrm{NT}$} & $\mathrm{C} 0$ & 0.00 & - & 0.00 & - \\
& $\mathrm{NSC}$ & 24.96 & 0.080 & 31.47 & 0.088 \\
& $\mathrm{SC}$ & 34.63 & 0.111 & 43.08 & 0.120 \\
\hline \multirow{2}{*}{$\mathrm{ST}$} & $\mathrm{C} 0$ & 0.00 & - & 0.00 & - \\
& $\mathrm{NSC}$ & 25.65 & 0.084 & 32.58 & 0.094 \\
& $\mathrm{SC}$ & 37.56 & 0.123 & 47.74 & 0.137 \\
\hline
\end{tabular}

NT =non-subsoiling tillage treatments; ST = subsoiling tillage treatments; $\mathrm{C} 0=$ untreated soil, NSC = non-sulphur compost treatment; $\mathrm{SC}=$ sulphur compost treatment, $\mathrm{RC}=$ relative change, $\mathrm{AE}=$ agronomic efficiency.

\section{Discussion}

Soil pH

Increasing soil $\mathrm{pH}$ with depth attributed to high content of $\mathrm{OM}$ in the surface layers compared with these in deeper layers (Antar et al. 2008; El-Sanat et al. 2017). High values of soil $\mathrm{pH}$ in the subsoiling treatments (ST) compared to non-subsoiling tillage treatment (NT) treatments may be resulted from, as decreasing of organic matter under subsoiling treatment where decomposition of organic matter is faster than that under untillage treatment. In this respect, the obtained results are similar to those found by Zhang et al. (2009) and Mohammad et al. (2012). The greatest decrease in soil $\mathrm{pH}$ resulting from the addition of both types of compost (SC; NSC) was probably caused from humic substances and acidic compounds produced from added compost (Calegari et al. 2013 and Abou Hussien et al. 2017). The superior effect of SC on the decrease of soil $\mathrm{pH}$ compared with that resulted from NSC additives resulted from its high content of sulphur (S) which oxidized by soil microorganisms to produce acidic compounds (Hashemimajd et al. 2012 and Saffari et al. 2013). Moreover, there is a high integration between the studied main 3 factors, which is reflected in their combined effect on the studied soil pH (El-Sanat et al. 2017).

\section{Soil EC}

The significant decrease of EC values with depth could be due to the clay soil texture which makes the soil water raises by capillary action to the upper layer of soil profile and evaporates leaving the salts which increases the soluble salts
(Zhang et al. 2009; Kheyrodin and Antoun, 2011 and Elbasiouny et al. 2017). The reason that ST tillage reduces soil EC values greater than NS tillage, perhaps because it improves porosity and hydraulic conductivity of the soil. Similar effect on salt affected soil porosity and hydraulic conductivity was found by Zhang et al. (2009) and El-Sanat et al. (2017). High decrease in soil EC in the soil treated with sulphur compost (SC) compared with these associated the treatments of non-sulphur compost (NSC) may be due to the solubility of soil organic or mineral compounds and its transformation from surface layers downwards with the drainage (Hashemimajd et al. 2012 and Saffari et al. 2013). Also, the positive interactions among different examined factors reflects the great harmony between it in terms of their effect on the soil EC.

\section{Soil OM}

The chemical, physical, and mineralogical properties of the parent material play an important role in the composition and amount of OM stored in the soil. This suggests that the control factors or their relative importance and the mechanisms involved in the stabilization and dynamics of soil OM may be different at the surface and in subsurface soil (Rumpel and Kögel-Knabner, 2011). The significant decreases in soil OM content that was associated with the ST tillage plots resulted from improving aeration condition, which led to an increase rate of OM oxidation and decomposition (Zhang et al. 2009 and Gajda et al. 2017). Also, the produced soluble organic compounds leached quickly with drainage water. More OM oxidation and leaching resulted from 
the increase of soil total porosity and hydraulic conductivity followed subsoiling tillage (LópezFando and Pardo, 2009 and Mohammad et al. 2012). The OM content (Table 2) of both additive compost (NSC; SC) was the reason for its high percentage in the treated soils compared to the control. Also, higher stability of SC compared to $\mathrm{NSC}$ and this due to $\mathrm{C} / \mathrm{N}$ ratio (Table 2) may be the reason for high significant $\mathrm{OM}$ content in the NSC treatments (Alidadi et al. 2013). These trends also reflect the high complementarity between the studied factors and their interaction on soil OM contents.

\section{Soil ESP}

Significant decreases in soil ESP values with increased depth has a strong correlation with clay soil content and its cation exchange capacity (CEC). Decreased soil content of clay with depth will be reflected in the values of soil CEC and hence, the adsorbed sodium (Table 1). Also, this trend may be due to the clay soil texture which makes the soil water raises by capillary action to the upper layer of soil profile carrying the cations as sodium (Ji et al. 2015). The decreases of soil ESP that associated with ST tillage could be related to increasing both of total soil porosity and its hydraulic conductivity and more Na leaching (Kheyrodin and Antoun, 2011; Gajda et al. 2017). The compost (SC; NSC) OM and $\mathrm{S}$ contents increased the solubility of $\mathrm{CaCO}_{3}$ and other compounds and therefore more soluble calcium replaced with $\mathrm{Na}^{+}$on the exchangeable sites (El-Sanat et al. 2017). More increase of soluble $\mathrm{Ca}^{2+}$ as a result of organic amendments applications were found by Ahmed (2019) and Elgezery (2016). Also, Abou Hussien et al. (2017) pointed out that, compost and sulphur applications either individual or in combination resulted in an increase of soil content of available $\mathrm{Ca}$. This confirms the agreement and positivity interactions among different studied factors in achieving the same goal.

\section{Soil available macronutrients}

The greatest values of the soil macronutrients $(\mathrm{N} ; \mathrm{P} ; \mathrm{K} ; \mathrm{S})$ in the surface layers compared to the deeper layer may be due to the soil clay and OM content accompanied these layers, which are characterized by high surface charge. In this respect Gómez-Rey et al. (2012), Ji et al. (2015) and Ladan and Jacinthe (2017) obtained on similar results. Decreased values of $\mathrm{N}, \mathrm{P}$, $\mathrm{K}$ and $\mathrm{S}$ in the soil treated with ST tillage may be resulted from the decrease of soil content of
$\mathrm{OM}$ and increase soil porosity and infiltration rate which led to leaching of the nutrients from different layers of soil profile. These results are in agreement with those obtained by Motavalli et al. (2003), Spiegel et al. (2007) and El-Sanat et al. (2017). Moreover, Significant increases in the values of the examined macronutrients, especially in soil amended with SC and NSC compost may be due to improve effects of added compost on soil chemical properties especially $\mathrm{pH}$ and its content of OM (Table 3) and also to the chemical composition of added compost (Table 2). Increases of nutrients with treatment of SC compared with NSC is due to the superior effect of $\mathrm{SC}$ on decreasing of soil $\mathrm{pH}$. These findings agree with obtained results by Hashemimajd et al. (2012), Alidadi et al. (2013), Elgezery (2016) and Abou Hussien et al. (2017). So, it can be said that the deep tillage with compost may be correct the found decrease in the soil content of available $\mathrm{N}, \mathrm{P}, \mathrm{K}$ and $\mathrm{S}$.

\section{Straw and grain yield of wheat plants}

Improving of soil physical and chemical properties and its content of available nutrients was considered the principle reason to explain the found increases in the straw and grains yield. The greatest positive effect of ST tillage on plant straw and grain yields could be related to its promotion and improvement of soil physical, chemical and biological properties especially the found decrease in both soil $\mathrm{pH}$ and EC. The increase effect of ST tillage on plant growth and productivity was pointed before that by Zhang et al. (2009), Mohammad et al. (2012), Ji et al. (2015), El-Sanat (2017) and Gajda et al. (2017). Also, the applied compost (NSC; SC) with advantage of SC increased the proportion of soil available macro-micronutrients which positively affected the yield of straw and grains for wheat plants. Similar increase effect of compost on many crops growth and productivity was found before that by Darwich et al. (2012), Elgezery (2016), Abou Hussien et al. (2017), Baddour et al. (2017), Ladan and Jacinthe (2017) and El-Akhdar et al. (2018) under different soil conditions.

\section{Conclusion}

The effect of subsoiling tillage and compost application on saline soil were evaluated under field experiment conditions. Subsoiling tillage (ST) and compost application particularly the treatments of sulphur compost (SC) have greatly improved chemical properties of saline soil. The soils treated with compost and / or subsoiling tillage had a decrease in pH, ESP and EC and increase in $\mathrm{OM}$ and soil available macronutrients 
(N, P, K and S). Subsoiling tillage a lone led to a significant decrease in ESP, EC, OM and the soil content of available $\mathrm{N}, \mathrm{P}, \mathrm{K}$ and $\mathrm{S}$, while there was slightly increasing in soil $\mathrm{pH}$. Moreover, treated saline soil with compost and subsoiling tillage had a high positive impact on increasing the productivity of wheat plant (c.v. Misr 2).

\section{Ethics approval and consent to participate}

This article does not contain any studies with human participants or animals performed by any of the authors.

\section{Consent for publication}

All authors declare their consent for publication.

\section{Funding}

This research received no external funding.

\section{Conflicts of Interest}

The author declares no conflict of interest.

\section{Author contribution}

Creating the work plan and writing the MS (E. A. Abou Hussien) and the contribution of the field and Lab work, writing the MS and statistical analyses (W. M. Nada and H. Mahrous).

\section{Acknowledgments}

We would like to express our sincere gratitude to Department of Soil Science, Faculty of Agriculture, Menoufia University for kindly providing and supporting.

\section{References}

Abdelaziz, S.M., Taha, M.B., Ibrahim, Sh. E.B. and Abo-Steet, S.Y.M. (2016) Effect of on-farm composted treated with some soil conditioners on soil fertility and productivity. Menoufia J. Agric. Res.41(2), 469-480.

Abou Hussien, E.A., Nada, W.M. and Elgezary, M.Kh. (2017) Evaluation efficiency of sulphur fertilizer in calcareous soil amended by compost. Menoufia J. Soil Sci. 2, 59-72.

Ahmed, B.M.A. (2019) Effect of soil conditioners on selectivity coefficient on some salt affected soil. Master Thesis, Faculty of Agriculture, Menoufia University, Egypt, 175 p.

Alidadi, H., Saffari, A.R. and Peiravi, R. (2013) Effects of Biofertilizers Effects of Compost, Vermicompost and Sulfur Compost on Yield of Saffron. World Appl. Sci. J. 21 (9): 1386-1390. DOI: 10.5829/idosi.wasj.2013.21.9.1188
Antar, S.A., El-Henawy, A.S. and Atwa, A.A. (2008) Improving some properties of heavy clay salt affected soil a result of different subsurface tillage. J. Agric. Sci. Mansoura Univ. 33 (10), 7675-7687.

Attard, E., Recous, S., Chabbi, A., De Berranger, C., Guillaumaud, N., Labreuche, J., Philippot, L., Schmid, B. and Le Roux, X. (2011) Soil environmental conditions rather than denitrifier abundance and diversity drive potential denitrification after changes in land uses. Glob. Chang. Biol. 17, 1975-1989.https://doi. org/10.1111/j.1365-2486.2010.02340.x

Baddour, A.G., Eman Rashwan and El-Sharkawy, T.A. (2017) Effect of Organic Manure, Antioxidant and Proline on Corn (Zea mays L.) Grown under Saline Conditions. Env.Biodiv. Soil Security, 1, 203 - 217. DOI: $10.21608 /$ jenvbs.2018.2513.1021

Calegari, A., Tiecher, T., Hargrove, W.L., Ralisch, R., Tessier, D., de Tourdonnet, S. and Dos Santos, D.R. (2013) Long-term effect of different soil management systems and winter crops on soil acidity and vertical distribution of nutrients in a Brazilian Oxisol. Soil Till. Res. 133, 32-39.https:// doi.org/10.1016/j.still.2013.05.009

Cottenie, A., Verloo, M., Kickens, L., Velghe, G. and Camerlynck, R. (1982) Chemical analysis of plants and soils. Laboratory of Analytical and Agrochemistry. State University, Ghent Belgium, pp: $100-129$.

Darwich, M.A., El-Maaz, E.I.M. and Ahmed, H.M.R.M. (2012) Effect of Mineral Nitrogen, Sulphur, Organic and Bio-Fertilizations on Some Physical and Chemical Properties and Maize Productivity in Saline Soil of Sahl El-Tina. J. Appl. Sci. Res.8 (12), 5818-5828.

El-Akhdar, I., Omara, A.E. and Abdel-Rahman, M.A. (2018) Intergradation of Different Fertilizers for Sustainable Agriculture Enhanced Growth and Yield of Wheat (Triticum aestivum L.). Env. Biodiv. Soil Security, 2, 11 - 23.DOI:10.21608/ jenvbs.2018.3479.1025

Elbasiouny, H., Elbehiry, F. and Abowaly, M. (2017) Soil Quality Indices; Special Focus on Saltaffected Soil: Review and Case Study in Northern Egypt. Env.Biodiv. Soil Security, 1, 85 - 100. DOI: 10.21608/jenvbs.2017.1085.1005

Elgezery, M.Kh. (2016) Effect of organic additives on efficiency of sulphur fertilization. Master Thesis, Faculty of Agriculture, Menoufia University, Egypt, 210 .

El-Sanat, GM.A., Aiad, M.A. and Amer, M.M. (2017) Impact of some soil amendment and different tillage depths on saline heavy clay soil properties and its yield water productivity. International

Env. Biodiv. Soil Security Vol. 4 (2020) 
Journal of Plant \& Soil Science 14 (2), 1-13. https://doi.org/10.9734/ijpss/2017/v14i23129

Fathi, A.I., Abdelaziz, S.M. and AbdElazeem, S.M. (2015) Rising rock phosphate efficiency for sesame productivity in sandy soil. Egypt Journal of Applied Science, 30 (1), 51-66.

Gajda, A.M., Czyż, E.A., Stanek-Tarkowska, J., Furtak, K.M. and Grządziel, J. (2017) Effects of long-term tillage practices on the quality of soil under winter wheat. Plant, Soil and Environment, 63, 236-242. https://doi.org/10.17221/223/2017-PSE

Gómez-Rey, M.X., Couto-Vázquez, A. and GonzálezPrieto, S.J. (2012) Nitrogen transformation rates and nutrient availability under conventional plough and conservation tillage. Soil Till. Res. 124, 144-152.https://doi.org/10.1016/j.still.2012.05.010

Hashemimajd, K., Farani, T.M. and Somarin, S.J. (2012) Effect of elemental sulphur and compost on electrical conductivity and phosphorus availability of one clay soil. Afr. J. Biotechnol. 11 (6), 14251432. https://doi.org/10.5897/AJB11.2800

Ji, Q., Wang, Y., Chen, X.N. and Wang, X.D. (2015) Tillage effects on soil aggregation, organic carbon fractions and grain yield in Eum - Orthic Anthrosol of a winter wheat-maize double-cropping system, Northwest China. Soil use manage. 31 (4), 504-514.https://doi.org/10.1111/sum.12213

Kheyrodin, H. and Antoun, H. (2011) Tillage and manure effect on soil physical and chemical properties and on carbon and nitrogen mineralization potentials. African Journal of Biotechnology, 10 (58), 9824-9830. https://doi. org/10.5897/AJB09.1025

Ladan, S. and Jacinthe, P.A. (2017) Nitrogen availability and early corn growth on plowed and no-till soils amended with different types of cover crops. J. Soil Sci. Plant Nutr. 17 (1), 74-90.http:// dx.doi.org/10.4067/S0718-95162017005000006

López-Fando, C. and Pardo, M.T. (2009) Changes in soil chemical characteristics with different tillage practices in a semi-arid environment. Soil \& Tillage research, 104 (2), 278 - 284. https://doi. org/10.1016/j.still.2009.03.005

Mohammad, W., Shah, S.M., Shehzadi, S. and Shah, S.A. (2012). Effect of tillage, rotation and crop residues on wheat crop productivity, fertilizer nitrogen and water use efficiency and soil organic carbon status in dry area (rainfed) of north-west Pakistan. J. Soil Sci. Plant Nutr. 12 (4), 715-727.

Motavalli, P.P., Stevens, W.E. and Hartwig, G. (2003) Remediation of subsoil compaction and compaction effects on corn $\mathrm{N}$ availability by deep tillage and application of poultry manure in a sandy-textured soil. Soil \& Tillage research 71 (2), 121 - 131. https://doi.org/10.1016/S01671987(03)00041-2

Nada, W.M. (2015) Stability and maturity of maize stalks compost as affected by aeration rate, $\mathrm{C} / \mathrm{N}$ ratio and moisture content. J. Soil Sci. Plant Nutr. 15 (3), 751-764.http://dx.doi.org/10.4067/S071895162015005000051

Page, A.L., Miller, R.H. and Keeney, D.R. (1982) Methods of Soil Analysis, Part 2. Chemical and Microbiological Properties. American Society of Agronomy. In Soil Science Society of America, Madison, Wisconsin, U.S.A. 1184 p.

Pitman, M.G. and Läuchli, A. (2002) Global impact of salinity and agricultural ecosystems. In Salinity: Environment-Plants-Molecules; Läuchli, A., Lüttge, U. (Ed.); Kluwer Academic Publishers: Dodrecht, The Netherlands, pp: 3-20.

Reeves, D.W. (1997) The role of soil organic matter in maintaining soil quality in continuous cropping systems. Soil Till. Res. 43, 131-167.https://doi. org/10.1016/S0167-1987(97)00038-X

Rumpel, C. and Kögel-Knabner, I. (2011) Deep soil organic matter-a key but poorly understood component of terrestrial C cycle. Plant Soil, 338, 143-158. https://link.springer.com/article/10.1007/ s11104-010-0391-5

Saeid, H.S. (2010) Effect of applied elemental sulphur and organic manure on increasing the fertility and productivity of a clayey soil. Egypt. J. Appl. Sci. 30 (1), 51-66.

Saffari, A.R., Alidadi, H., Najafpoorb, A.A. and Asadi, B. (2013) Effects of Compost, Vermicompost and Sulfur Compost on Scindapsus aureus Growth. Arch. Hyg. Sci. 2 (2), 55-61.

Snedecor, G.W. and Cochran, G.W. (1980) Statistical Methods 6th ed. Iowa State Univ. Press; Ames, Iowa; USA, 593 p.

Spiegel, H., Dersch, G., Hösch, J. and Baumgarten, A. (2007) Tillage effects on soil organic carbon and nutrient availability in a long-term field experiment in Austria. Die Bodenkultur, 58 (1), 47-58.

Tóth, G., Montanarella, L. and Rusco, E. (2008) Updated Map of Salt Affected Soils in the European Union Threats to Soil Quality in Europe; Official Publications of the European Communities: Luxembourg, Luxembourg, pp: 61-74.

Zhang, X., Li, H., He, J., Wang, Q. and Golabi, M.H. (2009) Influence of conservation tillage practices on soil properties and crop yields for maize and wheat cultivation in Beijing, China. Soil Res. 47 (4), 362-371.https://www.publish.csiro.au/SR/SR08110

Env. Biodiv. Soil Security Vol. 4 (2020) 